Resumen por el autor, C. V. Cowdry.

La tendencia conservadora en la nomenclatura citológica.

El autor considera con cierta aprehensión la multiplicidad creciente de los términos citológicos. Un análisis demuestra que algunos de ellos han sido introducidos para indicar ciertos atributos morfológicos; otros para designar ideas relativas a la constitución química; otros, de nuevo, para recordar los descubridores (introduciendo de este modo todo el problema de la prioridad) mientras que los más confusos han sido ideados para proclamar alguna interpretación funcional más o menos teórica. La confusión resultante es perjudicial para el pensar claro y retarda definidamente el progreso de la citología, pero ha de empeorar aún más hasta que los investigadores se hagan cargo suficientemente de la situación, considerando la introduccíon de nuevos términos sin buenas razones, como una especie de ofensa. Un cierto grado de tendencia conservadora es necesario. El autor indica que sería útil que alguna asociación nacional determinase los principios que han de inspirar la nomenclatura citológica para uso de los investigadores.

Translation by Jose F. Nonidez Cornell Medical College, New York 


\title{
CONSERVATISM IN CYTOLOGICAL NOMENCLATURE
}

\author{
E. V. COWDRY
}

The Laboratories of the Rochefeller Institute for Medical Research, New York

Repeated and ill-advised invention of new terms to designate cytoplasmic structures has resulted in considerable confusion.

A pathologist, for instance, who wants to review the literature on mitochondria is apt to be discouraged when told that, in order to be on the safe side, he must look for papers under at least a dozen different headings: bioblasts, chondriosomes, plastochondria, etc.

It is not without reason that biochemists and physiologists, who are able to help so much, are content to remain ignorant of advances in cytology. They are confronted by a mass of almost meaningless words which cannot be defined with anything approaching the accuracy to which they are accustomed. All too frequently they meet hypotheses which are absurd in the light of recent advances in physics and chemistry. A barrier is built up where the closest coöperation is needed. New and delicate methods are being devised for the measurement of temperature, electrical potental, ionization and other phenomena, which are of the utmost value to cytologists, but which their limited knowledge of physics and chemistry prevents them from using. Not infrequently the inventors themselves are unaware of the nature of the problems for which they are unconsciously supplying the means of solution.

The cytoplasmic material commonly called mitochondria (Benda, '98, p. 397) presents certain general properties, though the fact that it varies slightly in different cells suggests that it is in reality a mixture of chemical substances:

1. It may be easily seen to occur in living cells in the form of granules, rods, and filaments, and occasionally of networks, which vary in shape and in number in different conditions. 
Since their recognition as a definite class of cell granulation the literature has been flooded with new terms introduced by the authors with the best intentions and, in each case, in the firm belief that they would finally clarify the situation:2

\section{Benda ('98, p. 397) Chondriomitom \\ Benda ('99, p. 382) \\ Chondriomiten}

Benda (Van der Stricht, Chondriorhäbden '04, p. 105)

Benda (Van der Stricht, Chondriosomen '04, p. 105)

Benda (Van der Stricht, Chondriosphären '04, p. 105)

Renaut and Dubreuil Perinème ('06, p. 230)

\section{Renaut and Dubreuil Pericaryonème} ('06, p. 230)

\begin{tabular}{|c|c|}
\hline Koltzoff ('06, p. 468) & Mitogels \\
\hline Koltzoff' ('06, p. 468) & Mitosols \\
\hline Koltzoff ('06, p. 468) & Mitochondrosols \\
\hline Duesberg ('07, p. 284) & $\begin{array}{l}\text { Mitochondrial appa- } \\
\text { rat }\end{array}$ \\
\hline Meves ('07, p. 401) & Chondriokonten \\
\hline Meves ('07, p. 403) & Chondriom \\
\hline $\begin{array}{l}\text { Giglio-Tos and Granata } \\
(\text { '08, p. 14) }\end{array}$ & Chondriotaxie \\
\hline $\begin{array}{l}\text { Giglio-Tos and Granata } \\
\left({ }^{\prime} 08, \text { p. 1) }\right.\end{array}$ & Chondrioderese ${ }^{3}$ \\
\hline
\end{tabular}

Regaud ('09, p. 921) Eclectosomes

$\begin{array}{ll}\text { Meves ('10, p. 150) } & \text { Plastosomen } \\ \text { Meves ('10, p. 150) } & \text { Plastochondrien }\end{array}$

A feltwork of mitochondria Thread-like mitochondria Shaft-like mitochondria

A generic term to include all forms of mitochondria

Spherical mitochondria

Mitochondria as they occur in certain connective tissue cells

Mitochondria as they occur in certain connective tissue cells

Large mitochondrial masses formed by confluence

Mitochondrial droplets

Mitochondrial droplets

A general term, same as chondriom (Duesberg, '08, p. 261)

Rod-like mitochondria

Cytoplasmic content of mitochondria

The arrangement of granular mitochondria in threads

Division of mitochondria

To indicate supposed property of picking up substances from the surrounding medium and elaborating them

Generic term to include all forms of mitochondria

Granular mitochondria supposed to play a definite part in histogenesis

\footnotetext{
2 Rosenstadt's ('18, p. 193) 'tetrasomen' terminology is difficult to correlate.

${ }^{3}$ Comes (p. 423) claims priority over Giglio-Tos in the invention of this term. Since, however, he confuses the mitochondria with the reticular material, it is not clear under which heading it should be given.
} 
Meves ('10, p, 150)

Meves ('10, p. 150)

Laguesse ('11, p. 276)

Romeis ('12, p. 139)

Comes ('13, p. 423)

Comes ('13, p. 423)

Comes ('13, p. 423)

Comes ('13, p. 423)

Asvadourova ('13, p. Chromochondries 293)

Wildman ('13, p. 428)

Ciaccio ('13, p. 725)

Ciaccio ('13, p. 725)

Ciaccio $(13$, p. 725)

Champy ('13, p. 157)

Arndt ('14, p. 55)

Jordan and Ferguson ('16, p. 94)

Gatenby ('18, p. 223)

Gatenby ('18, p. 210)

Meves ('18, p. 273)

Guilhiermond ('1 239)
Trofo-condrioma

Karyochondria

Macromitosome

Chondriomer

Plastochondriomi-

ten

Plastoconten

Ergastidions

Chondriolysis

Condrio-cinesi

Condrio-dieresi

Idio-condrioma

Plastolysis

Plastorhexis

Präplastorhexis

Chondrioplastes

Caryosomochondria

Myochondria

Micromitochondria Macromitochondria

Mitochondries elab oratorices
Rows of granular mitochondria

Long rod-like mitochondria

To indicate supposed relation to ergastoplasm

Solution of mitochondria

Changes in mitochondria during cell division

Changes in mitochondria during cell division

Mitochondria supposed to play a defnite part as carriers of heredity

Mitochondria supposed to be concerned in nutrition

To indicate supposed part in pigment formation

To indicate supposed nuclear origin

Solution of mitochondria

Breaking up of mitochondria into granules and vesicles

Changes preliminary to plastorhexis

To indicate supposed part in formation of plastes

To indicate supposed origin from the caryosome

To indicate supposed mitochondrial origin of myofibrils

Small mitochondria which are less dense than the larger ones and behave differently in the spermatogenesis of certain invertebrates

Used synonymously with the mitochondrial coil (nebenkern or paranucleus) of Lepidoptera

Suggests termination 'er' for purely morphological nomenclature

To indicate mitochondria supposed to differentiate into chondrioplastes in the animal cell and into plastides in the vegetable cell 
Guilliermond ('19, p. Mitochondries vege- To indicate non-functional mi239) tatives tochondria which are thought to perpetuate the chondriome

Dangeard ('19)

Plastidome

(Quoting from Guilliermond '21, p. 73)

The reticular material cannot be so precisely defined, but we do know that under certain conditions it (or its mordant) has an affinity for silver; that after long immersion it blackens with osmic acid; and that, when fixed by appropriate methods (Bensley, '10, p. 191), it presents the form of a system of clear uncolored spaces. It may also be recognized by its morphology and by its position in the cell. Golgi ('98, p. 1) was the first to refer to its reticular shape. By substituting the general term 'material' in place of 'apparatus,' the idea of a definite system of canals is not sustained (Cowdry, '21, p. 8).

Like the mitochondria, it was occasionally seen by the older authors and described, together with other materials under many headings of which I have selected the following:

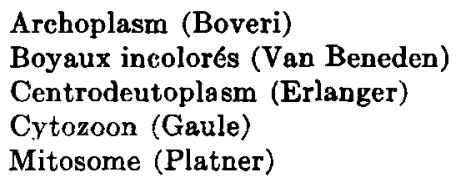

Stimulated by the discoveries of Golgi, Holmgren, and Kopsch, new terms are being devised wholesale:

\begin{tabular}{|c|c|c|}
\hline Holmgren ('99, p. 139) & Saftkanälchen & $\begin{array}{l}\text { Reticular material as clear } \\
\text { canals (negative picture) }\end{array}$ \\
\hline \multirow[t]{3}{*}{ Nelis ('99, p. 102) } & Spiremes & $\begin{array}{l}\text { Reticular material in the form } \\
\text { of clear, uncolored spaces }\end{array}$ \\
\hline & $\begin{array}{l}\text { Etát spiremateux du } \\
\text { protoplasma }\end{array}$ & $\begin{array}{l}\text { Reticular material in the form } \\
\text { of clear, uncolored spaces. }\end{array}$ \\
\hline & Bandes incolorés & $\begin{array}{l}\text { Reticular material in the form } \\
\text { of clear, uncolored spaces }\end{array}$ \\
\hline Kopsch ('02, p. 934) & $\begin{array}{l}\text { Binnennetz (Netz- } \\
\text { apparat) }\end{array}$ & Blackened reticular material \\
\hline Holmgren ('03, p. 9) & Trophospongium & $\begin{array}{l}\text { To indicate canals which pene- } \\
\text { trate the cell from the ex- } \\
\text { terior. Evidently not the } \\
\text { reticular material, which is } \\
\text { purely cytoplasmic, though } \\
\text { sometimes applied to it. }\end{array}$ \\
\hline
\end{tabular}


Cajal ('04, p. 25)

Fuchs ('04, p. 501)

Sánchez ('07, p. 167)

Cajal ('08, p. 123)

Perroncito ('09) (Duesberg, '11, p. 884)

Bensley ('10, p. 179)

Maccabruni ('10, p. 447) Retzıs-Holmgrenschen Kanälchen

Kuschakewitsch 310)

Terni ('14, p. 68)

King (Gatenby, '16, p. Acroblasts 418)

Stockard and Papanicolsou ('18, p. 39)

Idioectosome Idiophthartosome

Gatenby ('18 a, p. 403)

Chondrioplasts

Penfield ('20, p. 303) Retispersion

Penfield ('20, p. 303) Retisolution

Saguchi ('20, p. 388)

Saguchi ('20 a, p. 15)
Urano-argentophile apparatus
Same as 'red endocellular de Golgi'

Same as Saftkanälchen or reticular material in the form of clear, uncolored spaces

Homologue of 'Appareil de Golgi-Holmgren'

Conduits de Golgi- Reticular material as clear canals

To indicate the process of breaking up of reticular material into fragments during mitosis

The individual fragments

Reticular material as clear canals

To indicate tubular nature and discovery by Retzius and Holmgren

Reticular material during a phase of spermatogenesis

Reticular material grouped about the centrosome

"Dictyosomes or individual units of the Golgi apparatus" (Gatenby and Woodger, '21, p. 279)

Recticular material as it appears in certain stages of spermatogenesis

Same as 'Golgi rods' (i.e., rodlike masses of reticular material

To indicate dispersion of the reticular material to the cell periphery

Solution of the reticular material

"The apparatus which can be made manifest by various methods, such as Kopsch's and Wiegl's osmium method, Sjovall's formalin-water-osmium method, Cajal's uranic nitrate-silver method, and Golgi's arsenic method"

"Filamentous or granular corpuscles which can be made manifest by the Cajal uranic nitrate method" 
The so-called 'chromidal substance' is another cytoplasmic constituent of wide distribution encountered by many investigators, who, failing to realize the substantial similarity of the fundamental vital processes in different tissues, have called it all kinds of names. Specific granulations, occurring only in certain cell types, give us much less trouble.

We cannot take refuge in priority, which is very difficult to establish, because modern cytology is resolving itself more and more into a gradual approximation to a logical interpretation of living materials observed for the first time years ago with the aid of Abbe's condenser and the newly introduced apochromatic lenses. Newly recognized protoplasmic constituents are, for the most part, specific in nature, like secretion antecedents, not general in distribution, like the mitochondria, and are only revealed by refinements in microchemical technique. It is but natural that investigators should introduce terms indicative of their theoretical conceptions, but the habit is a bad one, because our ideas are changing so rapidly. Altmann's choice of the term 'bioblasts,' to indicate his belief that small fragments of material, which we now know to be mitochondria, were independent micro-organisms, attracted so much criticism and ridicule that his valuable discoveries were soon forgotten and investigations along this line were set back many years. Terms of this kind indicative of the supposed functional activities of cellular structures are often invented one year only to be cast aside the next, but they remain in the literature to mystify visitors from other sciences.

I question also the wisdom of using special terms to indicate slight differences in morphology; which after all can only be detected with oil-immersion lenses. In the case of mitochondria, we are dealing with fragments of material of microscopic size. Changes in form occur from moment to moment and are merely the expression of interaction between the mitochondria and the surrounding medium; only rarely do they indicate noticeable differences in chemical constitution.

Realizing that the cell is a living unit, which is changing continually, our terms should, it appears to me, be general and comprehensive, not limited and specific. While the materials in 
question continue to defy chemical analysis, the probability that they undergo progressive and important chemical changes, which are not revealed by our imperfect methods, should be entertained, and speculations as to their physiological rôle should be advanced with caution. Most of the structural differentiations recognized by cytologists are mixtures, not pure chemical substances, so that the problem is by no means a simple one.

Perhaps the greatest difficulties are met with during cytomorphosis. In spermatogenesis, for instance, the mitochondria appear to change into some kind of material fairly resistant to acetic acid and of different morphology and staining reaction. At what stage should we cease calling them mitochondria and speak only of the product, whatever it may be? The same difficulty is met with in the case of the reticular material. The introduction by Stockard and Papanicolaou ('18, p. 39) of the following terms, in connection with the development of the idiosome, is, in my opinion, of questionable value: calyptosome, karyogranulomes, idiogranulotheca, idiophthartosome, idiosphaerosome, idiosphaerotheca, cytogranulomes, cryptosome, idioectosome, idioendosome, idiogranulomes, spermiocalyptrotheca. I am inclined to agree with Duesberg's ('20, p. 8) usage in this connection. Since we are ignorant of the chemistry of the cytomorphic change, we have to come to some arbitrary decision in each instance, for every cell in the body as it grows old presents the same problem with respect to all its structural components.

So many and so varied are the structures which can be recognized in the nucleus and cytoplasm in normal as well as pathological conditions, the chemistry and physics of which we know next to nothing, that hundreds of terms are in every-day use, many of them synonymous. Specialization is carried so far that students of the cytoplasm become bewildered when first they interest themselves in nuclear structure, and investigators familiar with the nucleus have to go slowly in the terminology of leucocytic granulations and secretion antecedents, if, indeed, they ever consider them.

Our main problem is not an etymological one, but confusion in nomenclature reflects inaccuracy in methods of cytologic 
analysis and in the coördination of our knowledge of cellular physiology. It arises from the fact that our information regarding the chemistry of protoplasm is largely indirect and deducive. With the discovery of new methods of direct analysis and the strengthening of the mechanistic point of view, that we must try to explain vital phenomena in terms of physics and chemistry, investigators will be less ready to advance theories without carefully considering the chemical changes which they hypothecate, or to make unqualified statements of the transformation of one cytoplasmic material into another without knowing the constitution of either and the probability or improbability of such a change. With more accurate knowledge will come conservatism; the useful terms will gradually be sorted out and the bad ones consigned to oblivion. But this rapprochement between cytology and the more exact sciences will be a slow process extending over many years. In the meantime are we to follow the command of the old Chinese philosopher, Lao Tzu: "Practise inaction; content yourself with doing nothing"?

Some will say that it is not a matter which warrants group action, that the individual must continue to be a law unto himself, and that the very haziness of our knowledge of cellular structure will make it impossible to arrive at any modus operandi. The Basel anatomical nomenclature of visible structural components, a much easier task, has on the whole been of the greatest help. In chemistry, certain conventions in terminology are recognized even in respect to compounds about which very little is known and concerning which there is much speculation.

Individual preference will of course continue to be followed, but I cannot help thinking that an attempt by some national organization, or group of individuals, not to dogmatize further on terms, but rather to determine guiding principles in cytologic nomenclature for the use of investigators would be desirable. To yield the best results this committee or group should consist of students interested in the structure of both the nucleus and the cytoplasm as well as of a botanist, a protozoologist, and a biochemist, because cytology, dealing as it does with the minute structure of living material, is the broadest of biological sciences. 


\section{BIBLIOGRAPHY}

ARNDT, A. 1914 Ueber generative vorgänge bei Amocba chondrophora, n. sp. Arch.f. Protistenk., Jena, Bd. 34, S. 39-59.

Asvadodrova, N̈INa 1913 Recherches sur la formation de quelques cellules pigmentaires et des pigments. Arch. d'anat. micr., Par., T. 15, pp. $153-314$

BENDA, C. 1898 Ueber die Spermatogenese der Vertebraten und höheren Invertebraten. 2. Die Histiogenese der Spermien. Verhandl. d. physiol. Gesellsch. zu Berl., xxiii, 393-398.

1899 Weitere Mitteilungen über die Mitochondria. Ibid., Bd. 24, S. $376-383$.

BensLey, R. R. 1910 On the nature of the canalicular apparatus of animal cells. Biol. Bull., Bost., vol. 19, pp. 179-194.

Champy, C. 1913 Recherches sur la spermatogenése des Batraciens et les elements accessoires du testicle. Arch. de Zool. exper. et. gén. Hist. Nat., etc., Par., T. 52, pp. 13-304.

$\mathrm{C}_{\text {AJAL, }} \mathrm{S} . \mathrm{R} .1904 \mathrm{El}$ aparato tubiliforme del epitelio intestinal de los mamiferos. Trab. Lab. Invest. Biol., Maidrid, T. 3, pp. 35-38.

1908 Les conduits de Golgi-Holmgren du protoplasma nerveux et le réseau pericellulaire de la membrane. T. 6, pp. 123-136.

Ciaccio, C. 1913 Zur Physiopathologie der Zelle. Centralbl. f. allg. Path. u. path Anat., Jena, Bd. 24, S. 721-727.

Comes, S. 1913 Apparato reticolare o condrioma? Cariocinesi o dittocinesi. Anat. Anz., Leipz., Bd. 43, S. 422-438.

Cowdry, E. V. 1918 The mitochondrial constituents of protoplasm. Carnegie Institution, Wash., Contribution to Embryology, vol. 13, pp. 39-160. 1921 The reticular material of developing blood cells. J. Exper. M., N. Y., vol. 33, pp. 1-11.

Duesberg, J. 1907 Der Mitochondrial-apparat in den Zellen der Wirbelthiere und Wirbellosen. Arch. f. mikr. Anat., Bonn, Bd. 71, S. 284-296.

1911 Plastosomen, 'Apparato reticolare interno' und Chromidial apparat. Ergebn. d. Anat. u. Entwicklngsgesch., Wiesb., Bd. 20, S. $567-916$.

1920 Cytoplasmic structures in the seminal epithelium of the opossum. Carnegie Inst., Wash., Contributions to Embryology, vol. 9, pp. 49-84.

Fuchs, H. 1904 Ueber Beobachtungen an Sekret- und Flimmerzellen. Anat. Hefte, Wiesb., Bd. 25, S. 501-679.

Gatenby, J. Bronté 1916 The cytoplasmic inclusions of germ-cells. I. Lepidoptera. Quart. J. Micr. Sc., Lond., vol. 62, pp. 407-463.

1918 Part III. The spermatogenesis of some other pulmonates. Ibid., vol. 63, pp. 197-258.

1918 a Part IV. Notes on the dimorphic spermatozoa of Paludina and the giant germ-nurse cells of Testacella and Helix. Ibid., vol. 63, pp. 401-444.

Gatenby, J. Bronte, And Woodger, J. H. 1920 On the relationship between the formation of yolk and of the mitochondria and Golgi apparatus during oögenesis. J. Roy. Micr. Soc. Lond., vol. 251, pp. 129-156. 
Giguio-Tos, E., and Granata, L. 1908 I Mitochondrł nelle cellule seminali maschil: di Pamphagus marmoratus (Burm). Biologica, Torino, T. 2, no. 4, pp. 1-115.

GoLGI, C. 1898 Intorno alla struttura delle cellule nervose. Boll. d. Soc. med.-chir. di Pavia, T. 12, pp. 1-14.

Guilliermond, A. 1919 Sur l'origine mitochondriale des plastides. Ann. des Sci Nat., Botanique, Par., series 10, T. 1, pp. 225-244.

1921 Sur les éléments figurés du cytoplasme chez les végétaux: chondriome, appareil vacuolaire et granulations lipoides. Arch. de. Biol., Par., T. 31, pp. 1-82.

Holmgren, E. 1899 Zur Kenntnis der Spinalganglionzellen von Lophius piscatorius, Lin. Anat. Hefte, Wiesb., 1. Abt., Bd. 12, S. 75-151. 1903 Ueber die 'Saftkanälchen' der Leberzellen und der Epithelzellen der Nebenniere. Anat. anz., Leipz., Bd. 22, S. 9-14.

Jordan, H. E., AND Ferguson, J. S. 1916 A textbook of histology. New York: D. Appleton \& Co.

Koltzoff, N. K. 1906 Studien über die Gestalt der Zelle. I. Untersuchungen über die Spermien der Decapoden als Einleitung in das Problem der Zellengestalt. Arch. f. mikr. Anat., Bonn, Bd. 67, S. 364-571.

KopsCH, F. 1902 Die Darstellung des Binnennetzes in Spinal-Ganglienzellen und anderen Körperzellen mittelst Osmiumsäure. Sitzungsb. d. k. preuss. Akad. d. Wiss., Bd. 40, S. 929-935.

Kuschakewitsch, S. 1913 Studien über den Dimorphismus der männlichen Geschlechtselemente bei den Prosobranchia. I. Arch. f. Zellforsch., Leipz., Bd. 10, S. 237-323.

Lagdesse, E. 1911 Ergastoplasme et chondriome dans les cellules sécrétantes sereuses. Bibliog. anat., Par. and Nancy, T. 21, pp. 273-286.

Maccabruni, F. 1910 I megacariociti. Internat. Monatschr. f. Anat. u. Physiol., Leipz., Bd. 27, S. 447-489.

Meves, F. 1907 Ueber Mitochondrien bezw. Chondriokonten in den Zellen junger Embryonen. Anat. Anz., Leipz., Bd. 31, S. 399-407.

1910 Ueber Strukturen in den Zellen des embryonalen Stutzgewebes sowie über die Entstehung der Bindegewebsfibrillen, insbesondere derjenigen der Sehne. Arch. f. mikr. Anat., Bonn, Bd. 75, S. 149-208. 1918 Zur Kenntnis des Baues pflanzlicher Spermien. Ibid., Bd. 91, Abt. II; S. 272-311.

NeLIs, C. 1899 Un nouveau detail de structure du protoplasme des cellules nerveuses (étát spirémateux du protoplasme). Bull. de la cl. d. sc. de Belg., Brux., T. 37; pp. 102-125.

Penfield, W. G. 1920 Alterations in the Golgi apparatus in nerve cells. Brain, Lond., vol. 43, pp. 290-305.

REGAUD, C. 1909 Attribution aux 'formations mitochondriales' de la fonction generale d' extraction et de fixation électives 'exercée par les cellules vivantes' sur les substances dissoutes dans le milieu ambiant. C. rend Soc. de Biol., Par., vol. 61, pp. 919-921.

Renatt, J., Ex Dubreuil, G. 1906 Les cellules connectives de la lignée rhagiocrine. Bibliog. anat. Par. and Nancy, T. 15, pp. 222-242. 
Romers, B. 1912 Beobachtungen über Degenerationserscheinungen von Chondriosomen. Arch. f. mikr. Anat., Bonn, Bd. 80, pp. 129-170.

Rosenstadt, B. 1918 Zellstudien. Arch. f. mikr. Anat., Bonn, Bd. 91, Abt. 1, S. $182-207$.

SíguchI, S. 1920 Studies on the glandular cells of the frog's pancreas. Am. Jour. Anat., Phila., vol. 26, pp. 347-421.

1920 a Cytological studies of Langerhans's islets, with special reference to the problem of their relation to the pancreatic acinus tissue. Am. Jour. Anat., Phila., vol. 28, pp. 1-58.

Sínchez, O. 1907 L'appariel reticulaire de Cajal-Fusari des muscles striés. Trab. Lab. Invest. Biol, Madrid, T. 5, pp. 155-168.

Stockard, Charles R., and Papanicolaod, George N. 1918 The development of the idiosome in the germ cells of the male guinea-pig. Am. Jour. Anat., Phila., vol. 24, pp. 37-69.

Terni, T. 1914. Condriosomi, idiozoma e formazioni periidozomichi nella spermatogenesi degli Anfibi. (Richerche sul Geotriton fuscus). Arch. f. Zellforsch., Leipz., Bd. 12, S. 1-96.

VAN DeR Stricht, O. $1904 \mathrm{La}$ couche vitellogène et les mitochondries de l'oeuf des mammifères. Verhandl. d. anat. Gesellsch., Jena, Bd. 18, S. 138-145.

Wildman, E. E. 1913 The spermatogenesis of Ascaris megalocephala with special reference to the two cytoplasmic inclusions, the refractive body and the mitochondria: their origin, nature, and rôle in fertilization. Jour. Morph., vol. 24, pp. 421-450. 